\title{
Analysis of an Increase in the Efficiency of a Spark Ignition Engine Through the Application of an Automotive Thermoelectric Generator
}

\author{
JERZY MERKISZ, ${ }^{1}$ PAWEL FUC, ${ }^{1}$ PIOTR LIJEWSKI, ${ }^{1}$ \\ ANDRZEJ ZIOLKOWSKI, ${ }^{1,2}$ MARTA GALANT, ${ }^{1}$ \\ and MACIEJ SIEDLECKI ${ }^{1}$
}

1.-Faculty of Machines and Transport, Institute of Combustion Engines and Transport, Poznan University of Technology, Piotrowo st. 3, 60-965 Poznan, Poland. 2.-e-mail: andrzej.j.ziolkowski@put.poznan.pl

We have analyzed the increase of the overall efficiency of a spark ignition engine through energy recovery following the application of an automotive thermoelectric generator (ATEG) of our own design. The design of the generator was developed following emission investigations during vehicle driving under city traffic conditions. The measurement points were defined by actual operation conditions (engine speed and load), subsequently reproduced on an engine dynamometer. Both the vehicle used in the on-road tests and the engine dynamometer were fit with the same, downsized spark ignition engine (with high effective power-to-displacement ratio). The thermodynamic parameters of the exhaust gases (temperature and exhaust gas mass flow) were measured on the engine testbed, along with the fuel consumption and electric current generated by the thermoelectric modules. On this basis, the power of the ATEG and its impact on overall engine efficiency were determined.

Key words: Waste heat recovery, engine efficiency, ATEG, RDE

\section{INTRODUCTION}

According to the sustainable development policy implemented within the framework of the Europe 2020 strategy, it is necessary to reduce consumption of conventional energy sources (oil, gas, and coal) to build a competitive, low-carbon economy. ${ }^{1,2}$ This policy is implemented through a number of legal norms that imply limiting emissions of greenhouse gases (GHGs), especially $\mathrm{CO}_{2}$. In 2007, the European Commission (EC) proposed a 30\% reduction of greenhouse-gas emissions in developed countries by the year 2020, and suggested that the European Union itself should make a firm independent commitment to achieve at least a $20 \%$ reduction in greenhouse-gas emissions. ${ }^{2}$ For the automotive industry, road emissions standards

(Received September 9, 2015; accepted April 12, 2016;

published online May 19, 2016) were introduced for either $\mathrm{CO}_{2}$ emission or fuel consumption (Table I).

According to Aren et al., ${ }^{1} \mathrm{CO}_{2}$ emissions from the road transport sector constitute $16.4 \%$ of global emissions. Powering vehicles is currently responsible for $38 \%$ of annual global demand for oil. ${ }^{1}$

To meet such $\mathrm{CO}_{2}$ emissions limits, road-vehicle manufacturers will have to implement new, innovative solutions. Currently, the basic directions of development of spark ignition (SI) engines are downsizing, use of gasoline direct injection systems, as well as variable valve timing and valve lift. A variable geometric compression ratio during engine operation is also used. There are two types of downsizing: static and dynamic. ${ }^{3}$ Static downsizing typically refers to reduction of the geometric dimensions of the engine-often by reducing the number of cylinders or displacement volume. Another possibility is to deactivate cylinders during the combustion engine work cycle-known as dynamic downsizing. 
Table I. $\mathrm{CO}_{2}$ emission and fuel consumption norms around the world ${ }^{1}$

\begin{tabular}{|c|c|c|c|c|c|}
\hline $\begin{array}{l}\text { Country } \\
\text { or region }\end{array}$ & Target year & Standard type & Unadjusted fleet target & Test cycle & Penalties \\
\hline \multirow[t]{2}{*}{ EU } & 2015 & $\mathrm{CO}_{2}$ & $130 \mathrm{gCO}_{2} / \mathrm{km}$ & $\begin{array}{l}\text { NEDC (WLTP } \\
\text { from 2017) }\end{array}$ & Economic fines \\
\hline & 2021 & & $90 \mathrm{gCO}_{2} / \mathrm{km}_{2}$ & WLTP & \\
\hline \multirow[t]{2}{*}{ Japan } & 2015 & Fuel economy & $16.8 \mathrm{~km} / \mathrm{dm}^{3}$ & $\mathrm{JC08}$ & Economic fines \\
\hline & 2020 & & $20.3 \mathrm{~km} / \mathrm{dm}^{3}$ & & Public proclamation \\
\hline \multirow[t]{2}{*}{ Canada } & 2016 & $\mathrm{CO}_{2}+$ other GHGs & $217 \mathrm{gCO}_{2} / \mathrm{mi}$ & US combined & Economic fines \\
\hline & 2025 (proposed) & & N/A & & Sales restriction \\
\hline India & $\begin{array}{c}\text { From } 2016 \\
2021\end{array}$ & $\mathrm{CO}_{2}$ & $\begin{array}{l}(130 \mathrm{~g} / \mathrm{km}) \\
113 \mathrm{~g} / \mathrm{km}\end{array}$ & $\begin{array}{c}\text { NEDC for } \\
\text { low-powered vehicle }\end{array}$ & Not available \\
\hline \multirow[t]{2}{*}{ China } & 2015 & Fuel consumption & $6.9 \mathrm{dm}^{3} / 100 \mathrm{~km}$ & NEDC & Economic fines \\
\hline & 2020 (proposed) & & $5 \mathrm{dm}^{3} / 100 \mathrm{~km}$ & & Public proclamation \\
\hline USA & $\begin{array}{l}2016 \\
2025\end{array}$ & $\begin{array}{c}\text { Fuel economy/CO } \mathrm{CO}_{2} \\
\text { + other } \mathrm{GHGs}\end{array}$ & $\begin{array}{l}36.2 \mathrm{mpg} \text { or } 225 \mathrm{~g} / \mathrm{CO}_{2} \mathrm{~km} \\
56.2 \mathrm{mpg} \text { or } 143 \mathrm{gCO}_{2} / \mathrm{km}\end{array}$ & US combined & $\begin{array}{l}\text { Economic fines } \\
\text { Sales restriction }\end{array}$ \\
\hline South Korea & 2015 & $\begin{array}{l}\text { Fuel economy/CO } \mathrm{CO}_{2} \\
\text { + other GHGs }\end{array}$ & $17 \mathrm{~km} / \mathrm{dm}^{3}$ or $140 \mathrm{gCO}_{2} / \mathrm{km}$ & US combined & Public proclamation \\
\hline Mexico & 2016 & $\begin{array}{c}\text { Fuel economy/CO } \mathrm{CO}_{2} \\
\text { + other GHGs }\end{array}$ & $39.3 \mathrm{mpg}$ or $140 \mathrm{gCO}_{2} / \mathrm{km}$ & US combined & Economic fines \\
\hline
\end{tabular}

The aforementioned methods aim to increase the overall efficiency of the engine, thereby reducing its fuel consumption while maintaining the generated power output. ${ }^{4}$ Most of the chemical energy contained in the fuel is drained through the cooling system, as well as in the form of heat and pressure in exhaust gases. There is great potential for heat energy recovery from exhaust gases, as its share in the energy balance for SI engines can be as high as $45 \%$. For CI engines, it is assumed that the share of thermal energy loss in the exhaust gases is a maximum of $35 \%$. For this reason, systems that work in the Clausius-Rankine cycle as well as thermoelectric generators for automotive applications (ATEGs) have been developed and implemented. ${ }^{5-10}$

\section{CHOOSING A COMBUSTION ENGINE FOR RESEARCH}

For analysis of increased spark ignition (SI) engine efficiency through heat recovery from exhaust gases using an ATEG, Volkswagen's modern TSI 1.2- $\mathrm{dm}^{3}$ engine was selected (Fig. 1). This engine is a consequence of the strategy adopted by the company, which relies on implementation of engine downsizing. One of the first solutions of this type was the TSI $1.4-\mathrm{dm}^{3}$ engine. The selected combustion engine was primarily developed to meet $\mathrm{CO}_{2}$ emissions requirements. According to the manufacturer, ${ }^{*}$ the Audi A3 vehicle, equipped with two versions of the model TFSI 1.2-l engine with power of $63 \mathrm{~kW}$ and $77 \mathrm{~kW}$, reaches $\mathrm{CO}_{2}$ emissions of $118 \mathrm{~g} / \mathrm{km}$ and $127 \mathrm{~g} / \mathrm{km}$, respectively, in the NEDC test. These values are significantly lower than the established limit, which in 2015 equals $130 \mathrm{~g} / \mathrm{km}$.

*Information from the vehicle producer.

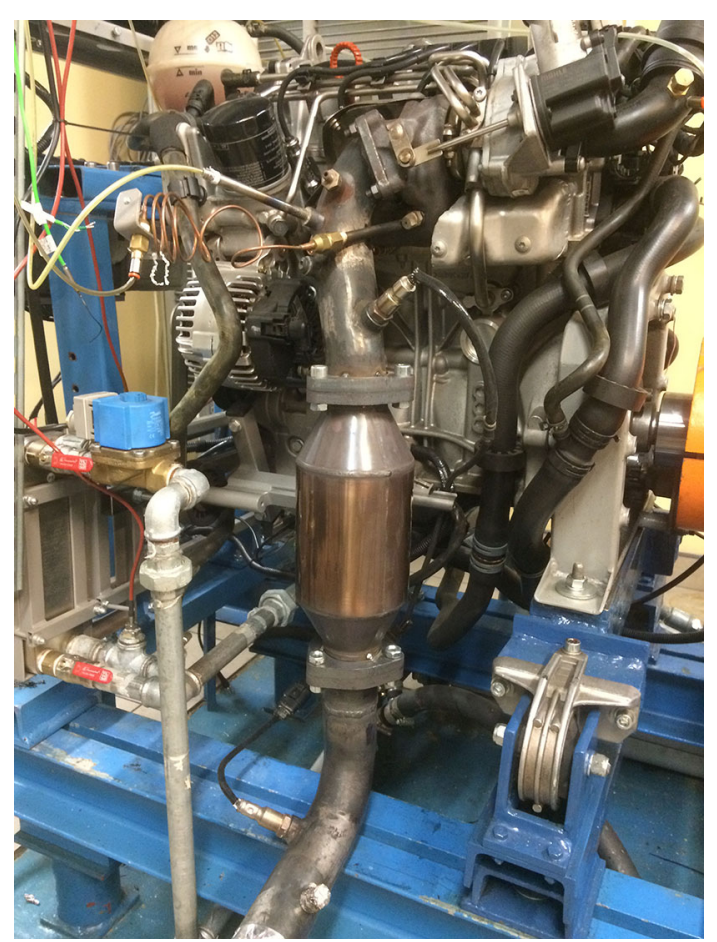

Fig. 1. 1.2- $\mathrm{dm}^{3} \mathrm{TSI}$ combustion engine chosen for this research.

The engine block is made of aluminum with innovative cast-iron cylinder liners. It uses two valves per cylinder. The inlet valve jacks have a special shape, which is responsible for producing a swirl type of turbulence that facilitates formation of a homogeneous air-fuel mixture. The engine crankshaft is made of steel with reduced diameter of the main journal and crank bearings with light connecting rods, which is meant to reduce friction losses. The engine has a gasoline direct injection 
system with six-hole injectors that generate injection pressure of 45 bar to 125 bar. To achieve high volumetric power, the engine is equipped with a turbocharger with an exhaust wastegate valve.

To determine the actual driving profile as a function $V=f(t)$, tests under actual operating conditions were performed using advanced research tools, including a portable emissions measurement system (PEMS). The tests were performed on a test route with total length of $12.6 \mathrm{~km}$. When selecting the test route, the authors aimed to reproduce typical urban (involving frequent vehicle stops) and suburban conditions. The selected test route met the said requirements. The "urban" part included highly congested streets and involved a variety of intersections. The "suburban" part was a portion of the road number 92-one of the main eastern entrance roads to the Poznan agglomeration. Such varied road conditions allow analyses to be conducted under a wide range of speeds and varied accelerations. This influences the effective engine parameters, which translate directly into the amount of thermal energy in the exhaust gases.

\section{DETERMINING THE POWER BAND OF THE ENGINE BASED ON MEASUREMENTS MADE WITH THE RDE METHODOLOGY}

To determine the engine power band for test bench investigation of the heat recovery from the exhaust gases, tests were carried out under real operating conditions in accordance with the real driving emissions (RDE) methodology. This study selected a vehicle equipped with a $1.2-\mathrm{dm}^{3}$ TSI engine, which was also located on an engine dyno station. Measurements were made using the latest PEMS instrument-the SEMTECH ECOSTAR. This is another device from the SEMTECH ${ }^{\circledR}$ series-a successor to the SEMTECH DS analyzer. The main difference between these devices is that the SEMTECH ECOSTAR is made up of separate modules (Fig. 2): ${ }^{11}$

1. Fuel economy meter (FEM) module for measuring the concentration of $\mathrm{CO}_{2}, \mathrm{CO}$, and total hydrocarbons (THC) using a nondispersive infrared (NDIR) analyzer,

2. $\mathrm{NO}_{x}$ module for measurement of $\mathrm{NO}_{x}$ (NO and $\mathrm{NO}_{2}$ ) concentrations using a nondispersive ultraviolet (NDUV) analyzer,

3. Flame ionization detector (FID) module to measure THC,

4. Power distribution module (PDM) to supply power to each component.

When all the modules (of the gas measurement section) are used, they must be connected together by a controller area network (CAN; green lines in Fig. 3). The FEM module is connected via a special cable to a flow meter for measuring thermodynamic parameters of exhaust gases (mass flow, temperature, and pressure). This line is supplied a sample of exhaust gases that passed through the NDIR analyzer (measuring $\mathrm{CO}_{2}, \mathrm{CO}$, and THC), directed to the $\mathrm{NO}_{x}$ module with three connectors, wherein measurements of $\mathrm{NO}$ and $\mathrm{NO}_{2}$ take place. Apart from the exhaust gas sample, a special conduit transmits the signal from the vehicle global positioning system (GPS) and a weather sensor used to measure atmospheric conditions (temperature, pressure, and humidity), which are connected to the flow meter. A computer for system control and a signal converter from the vehicle's diagnostic system are connected using an AUX2 connector to the PDM, FEM, and $\mathrm{NO}_{x}$ modules. Each module is equipped with one AUX1 and one AUX2 connection point. The signal from the power supply module for the heated wire is sent to the FID module. The SEMTECH ECOSTAR device can be powered by a PDM module, to which voltage is supplied from the grid or the car battery. It is also possible to directly

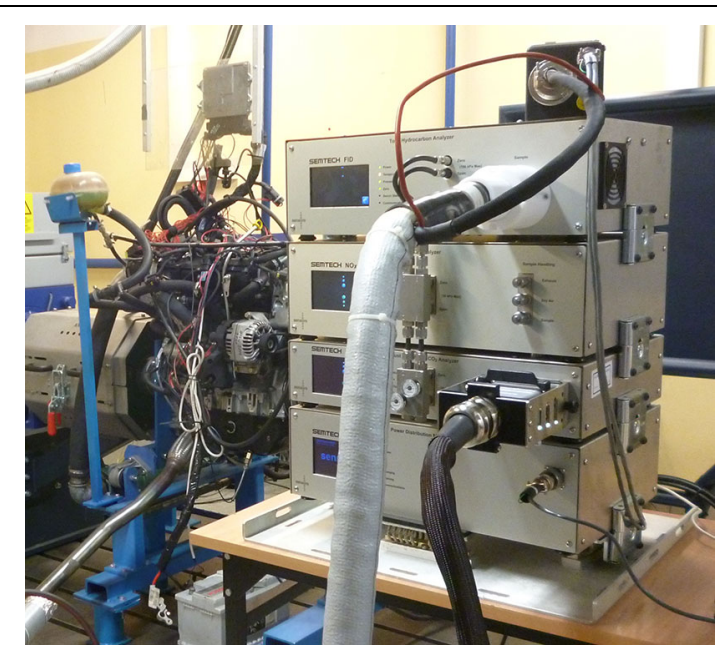

Fig. 2. SEMTECH ECOSTAR instrument, used to measure emissions in accordance with the RDE methodology.

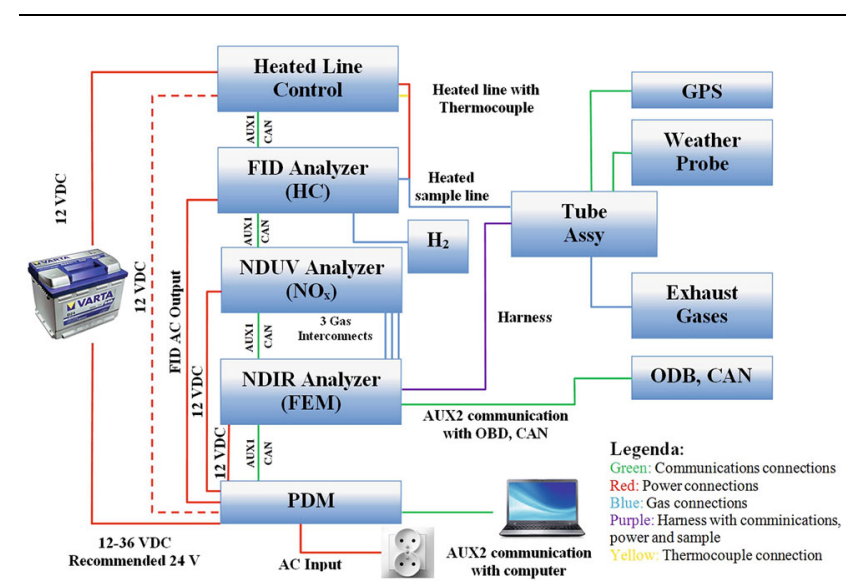

Fig. 3. Diagram of SEMTECH ECOSTAR system used for testing-section responsible for measurement of gaseous compounds. 
connect the modules to the mains. Due to the modular design of the instrument, it can perform measurements of all gaseous compounds simultaneously, or separately using single modules.

For the purposes of this study, only measurements of $\mathrm{CO}_{2}$ and $\mathrm{CO}$ (FEM module), thermodynamic parameters of exhaust gases (temperature, pressure, and mass flow rate), as well as weather conditions and vehicle speed and position were taken. These measurements were performed under real operating conditions on a designated route with length of $12 \mathrm{~km}$. A detailed description of the test route is given in Refs. 8 and 12. Measurements were carried out on a weekday afternoon.

On the basis of the measurements taken in accordance with the RDE methodology, the characteristics of the share of working time intervals in relation to crankshaft speed and engine load for the tested vehicle were determined, as presented in a three-dimensional (3D) graph in Fig. 4. The power band of engine operation was defined as the average time in the range of $400 \mathrm{rpm}$ and $20 \mathrm{Nm}$. For more than half of the total test time, the engine was in the range of $1400 \mathrm{rpm}$ to $3000 \mathrm{rpm}$ with load not exceeding $100 \mathrm{Nm}$. Single points of work, whose share accounted for only $3 \%$, were recorded above this range. The share of idling time amounted to $31 \%$.

The registered operating points of the combustion engine are presented with the full power characteristic as a two-dimensional (2D) graph in Fig. 5, from which it can be determined that the engine was mainly operating in the crankshaft rotational speed range of $1500 \mathrm{rpm}$ to $3500 \mathrm{rpm}$, where the torque is maximum. The combustion engine did not reach the value of $177 \mathrm{Nm}$. The maximum torque obtained in the road test was $144 \mathrm{Nm}$. No operating points were registered in the range of maximum engine crankshaft speed. This distribution of engine operating points stems directly from the route used in the test. The route has an urban section, where the vehicle

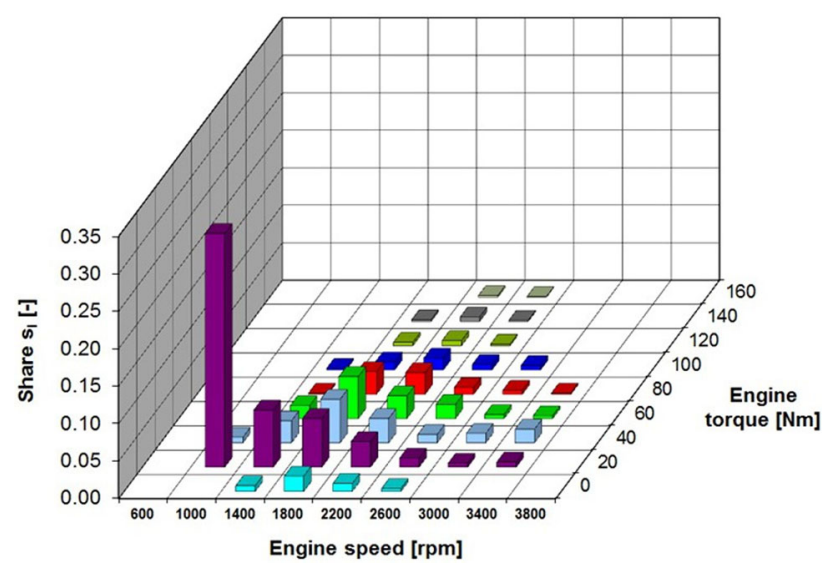

Fig. 4. Time share characteristics in the range of engine crankshaft speeds and loads in a test carried out in accordance with RDE methods. speed limit is $50 \mathrm{~km} / \mathrm{h}$, and a suburban section, where the limit is $70 \mathrm{~km} / \mathrm{h}$. There are also parts of the route which have a $30 \mathrm{~km} / \mathrm{h}$ or $40 \mathrm{~km} / \mathrm{h}$ speed limit. As a result of this, the vehicle cannot obtain a high average speed during the test cycle, which results in the engine operating at low and medium loads. During the research, the vehicle reached a maximum speed of $77 \mathrm{~km} / \mathrm{h}$ and its average speed was $33.2 \mathrm{~km} / \mathrm{h}$.

To best mimic the registered working conditions of the test vehicle's drive unit when testing on the engine dyno bench, it was decided that the research would be carried out at three different load characteristics with a constant speed of the engine crankshaft with load changed in 20-Nm intervals (Fig. 5, marked with pink dots): $1800 \mathrm{rpm}$ (six operating points), $2200 \mathrm{rpm}$ (five operating points), and $2800 \mathrm{rpm}$ (four operating points). The study also included the engine idling state $(800 \mathrm{rpm})$. This gives a total of 16 operating points for the engine, at which tests were carried out under laboratory conditions.

\section{RESEARCH METHODOLOGY USED FOR ENGINE DYNO TEST BENCH}

Measurements of heat recovery from the exhaust gases were carried out on a static engine dyno test bench from Automex company, on which the 1.2$\mathrm{dm}^{3}$ TSI engine was mounted, generating a maximum power output of $77 \mathrm{~kW}$ at $5000 \mathrm{rpm}$ (Table II). The volumetric power indicator of this drive unit is $64.2 \mathrm{~kW} / \mathrm{dm}^{3}$. The engine meets the Euro 5 emission standards and is equipped with a three-way catalytic (TWC) converter.

The study used the prototype ATEG developed by the authors as part of the Applied Research Programme funded by the National Centre for Research and Development (Fig. 6; Table III). This ATEG is modular and consists of three main elements: a heat exchanger, commercial thermoelectric modules, and cooling elements. The main

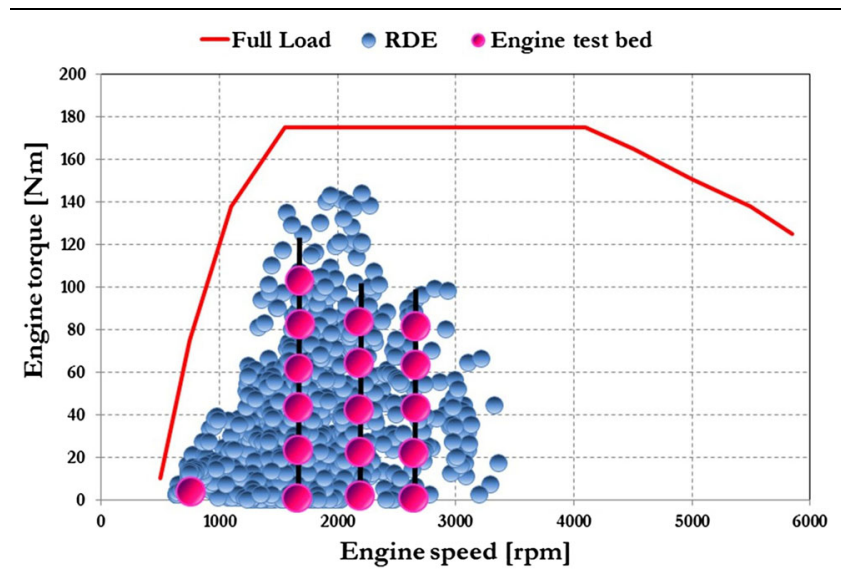

Fig. 5. Operating points for the engine of the test vehicle achieved in a test carried out in accordance with RDE methods with its full power characteristic. 
Table II. Parameters of the tested $1.2-\mathrm{dm}^{3}$ TSI engine

\begin{tabular}{lc}
\hline Parameter & Value \\
Type of engine & Spark ignition \\
Displacement & $1.2 \mathrm{dm}^{3}$ \\
Number of cylinders & 4 \\
Stroke & $75.6 \mathrm{~mm}$ \\
Bore & $71 \mathrm{~mm}$ \\
Number of valves & 2 \\
per cylinder & \\
Power output & $77 \mathrm{~kW}$ at $5000 \mathrm{rpm}$ \\
Torque & $175 \mathrm{Nm}$ at $1550 \mathrm{rpm}$ \\
& to $4100 \mathrm{rpm}$ \\
Emissions standard & Euro 5 \\
Exhaust gas & TWC with lambda control \\
posttreatment & \\
\hline
\end{tabular}

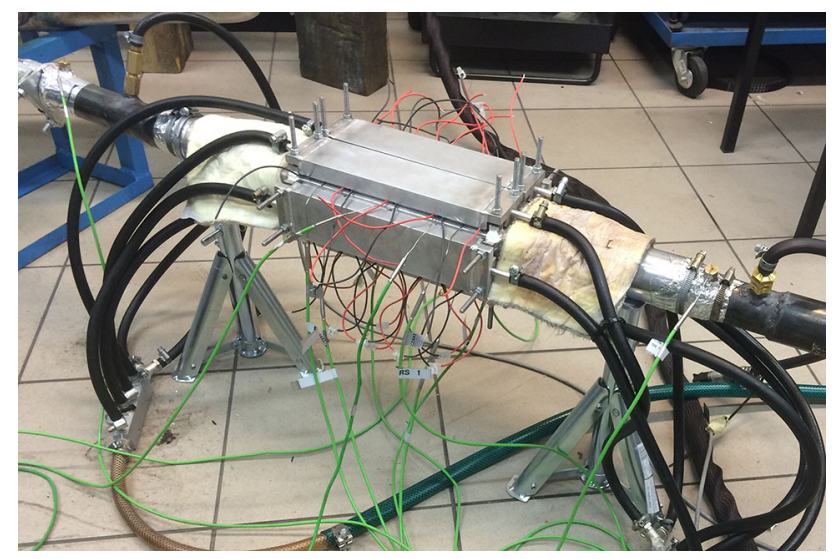

Fig. 6. ATEG installed in the engine testbed.

part of the heat exchanger, onto which the thermoelectric modules are arranged, has a rectangular shape.

Its width is almost twice its height. To ensure a uniform temperature distribution along the heat exchanger, ribbing with increasing cross-section was implemented inside it. It was assumed that four modules were arranged longitudinally on each side of the heat exchanger. There are two rows of modules on the top and bottom sides of the heat exchanger, and one row on each side, for a total of 24 modules. There is one dedicated cooling panel for each row of modules, attached to the heat exchanger by means of a screw connection. Each radiator is screwed to a heat exchanger using four screws placed at its corners. To ensure uniform pressure of the modules on the wall of the exchanger, an additional locking system was also used in the middle of the radiators. The screws were tightened to maximum torque of $20 \mathrm{Nm}$. This allows use of thermoelectric modules of different thickness. A special silicated thermal grease was applied between the modules and the walls of the heat exchanger to facilitate heat transfer from the walls
Table III. ATEG characteristics

\begin{tabular}{lc}
\hline Parameter & Value \\
Length & $671 \mathrm{~mm}$ \\
Width & $200 \mathrm{~mm}$ \\
Height & $135 \mathrm{~mm}$ \\
Inlet diameter & $60 \mathrm{~mm}$ \\
Material & Aluminum alloy with \\
Number of modules & thickness of $2 \mathrm{~mm}$ \\
Module arrangement & 24 \\
& Top and bottom \\
& walls-two rows \\
& with four modules each; \\
Type of modules used & side walls-one row \\
& with four modules \\
Number of cooling panels & TMG-241-1.4-1.2 by \\
Generated nominal power & Ferrotec NORD \\
Generated nominal & 6 \\
voltage without load & $225.6 \mathrm{~W}$ \\
Generated nominal & $300 \mathrm{~V}$ \\
voltage with load & $151.2 \mathrm{~V}$ \\
\hline
\end{tabular}

of the heat exchanger to the hot side of the module and help reduce possible heat leaks arising from the surface roughness of the heat exchanger and other material imperfections and faults.

The study used 24 commercial Ferrotec SCTB NORD thermoelectric modules codenamed TMG241-1.4-1.2, ${ }^{13}$ connected in series. These modules are $\mathrm{Bi}_{2} \mathrm{Te}_{3}$ based, and each can generate $9.4 \mathrm{~W}$ of power. The maximum temperature of the hot side of the module may not exceed $200^{\circ} \mathrm{C}$ when using thermally conductive paste. Without conductive paste, the temperature should not exceed $175^{\circ} \mathrm{C}$. The module generates a maximum voltage of $12.5 \mathrm{~V}$ with no load, and $6.3 \mathrm{~V}$ with load. The modules were chosen based on previous research experience of the authors with heat recovery from exhaust gases using ATEG. Reference ${ }^{8}$ presents the results of a TEG with a different design, using an earlier version of the TMG-241-1.4-1.2 modules, whose maximum power was $7 \mathrm{~W}$. These were selected on the basis of measurements showing that they achieved satisfactory operating parameters while maintaining resistance to the effects of high temperatures. The TMG-241-1.4-1.2 modules are characterized by high durability due to the nature of the joining techniques, junction materials, and diffusion barriers. For this reason, in the prototype ATEG which is the subject of this study, the authors used a newer version of the TMG-241-1.4-1.2 modules from SCTB NORD A Ferrotec Group Company. During the tests of heat recovery from exhaust gases performed on the static engine test bench, the following parameters were measured:

(a) Instantaneous fuel consumption $G(\mathrm{~g} / \mathrm{s})$, using a mass fuel gauge from Automex company, 
(b) Crankshaft rotational speed $s$ (rpm) and engine torque $T(\mathrm{Nm})$, using the stationary engine dyno test bench made by Automex company, equipped with an eddy-current brake and inductive engine speed sensor,

(c) Exhaust mass flow rate EFM $(\mathrm{kg} / \mathrm{h})$, using the SEMTECH ECOSTAR,

(d) Exhaust gas temperature at four measurement points $t_{1}, t_{2}, t_{3}$, and $t_{4}\left({ }^{\circ} \mathrm{C}\right)$, using thermocouples,

(e) Temperature of the hot side of the thermoelectric modules $t_{11}, t_{12}, t_{21}, t_{22}, t_{31}, t_{32}, t_{41}$, $t_{42}, t_{51}, t_{52}, t_{61}$, and $t_{62}\left({ }^{\circ} \mathrm{C}\right)$ (first and last module in each row), using thermocouples,

(f) Mass flow $m_{\text {cool }}\left(\mathrm{dm}^{3} / \mathrm{h}\right)$ and temperature $t_{\text {cool }}$ $\left({ }^{\circ} \mathrm{C}\right)$ of the coolant,

(g) Voltage $U(\mathrm{~V})$ and current $I(\mathrm{~A})$ generated by the modules, using a custom-made measurement system of the authors' design.

To register the temperatures and pressures, two IOTECH Personal Daq/3000 signal converters were used. The measurement module was equipped with a universal serial bus (USB) interface and highspeed analog-to-digital (A/D) converter (1 MHz/ 16 bit). The transmitter has 16 single-ended-type analog inputs (8 differential inputs), 4 analog outputs, and 24 digital input/output lines, and it is possible to program the device in seven ranges from $\pm 100 \mathrm{mV}$ to $\pm 10 \mathrm{~V}$. Information from the sensor is transmitted to a computer, which records the data at a given frequency.

The custom measurement system to measure the voltage and current generated by the modules consists of: the main module (which includes, among others, a USB-600 measuring card manufactured by National Instruments having eight analog inputs and four digital inputs), two converters for voltage and current measurements fitted on a printed circuit board (PCB), a slide resistor for setting the load of the system, as well as control software. The main module is supplied with a voltage of $220 \mathrm{~V}$. The software allows for monitoring of the generated voltage and current in real time (in numerical and graphical form) as well as data recording at a frequency of $1 \mathrm{~Hz}$. It uses algorithms to calculate the generated power in watts and the energy expressed in $\mathrm{kWh}$. A measuring device records the total value of voltage and current of all modules, but also has the ability to measure these values for individual modules.

\section{ANALYSIS OF RESULTS}

The overall efficiency of an internal combustion engine is a measure of its use of the energy contained in the fuel. It provides insight into the conversion efficiency of chemical energy contained in the fuel into mechanical energy output by the motor to the power receiver. This efficiency is also described as the inverse of the specific fuel consumption and can be expressed by the formula

$$
\eta_{0}=\frac{P_{\mathrm{e}}}{G \cdot \mathrm{GCV}}=\frac{1}{\mathrm{BSFC} \cdot \mathrm{GCV}},
$$

where $\eta_{0}$ is the overall efficiency $(-), P_{\mathrm{e}}$ is the engine power output $(\mathrm{kW}), G$ is the instantaneous fuel consumption $(\mathrm{g} / \mathrm{s})$, BSFC is the specific fuel consumption $(\mathrm{g} / \mathrm{kWh})$, and GCV is the gross calorific value $(\mathrm{J} / \mathrm{g})$.

To determine the total efficiency of an internal combustion engine using an ATEG, the power generated by the generator $P_{\text {eATEG }}$ needs to be included in Eq. 1, as follows:

$$
\eta_{\mathrm{E}+\mathrm{ATEG}}=\frac{\left(P_{\mathrm{e}}+P_{\mathrm{ATEG}}\right)}{G \cdot \mathrm{GCV}}=\frac{\left[P_{\mathrm{e}}+(U \cdot I)_{\mathrm{ATEG}}\right]}{G \cdot \mathrm{GCV}} .
$$

Such addition of the power generated by the ATEG $P_{\text {eATEG }}$ to the power output of the engine $P_{\mathrm{e}}$ is justified because the generator produces electrical power from the thermal energy of the exhaust gases after fuel combustion, which in an internal combustion engine is treated as waste as the heat created by burning the air-fuel mixture is not used. This increases the overall efficiency of the engine, because a greater amount of energy is obtained from the combustion produced by the same amount of fuel. In this way, the heat loss in the exhaust gases is also limited.

The determination of the overall engine efficiency on the engine dyno bench used the measured parameters of crankshaft speed and engine load (used to calculate the engine power output) and the fuel consumption per second $G_{\mathrm{s}}$. This consumption can also be calculated from the emissions per second of $\mathrm{CO}_{2}, \mathrm{CO}$, and $\mathrm{THC}$ in accordance with the carbon balance method as modified by the authors. ${ }^{14}$ As part of the tests carried out, the relationship between the fuel consumption (as measured by Automex instrumentation) and the consumption calculated on the basis of the parameters measured by the PEMS equipment was determined; more than 30 trials were performed for each operating point of the engine, which statistically can be treated as a large test sample. Figure 7 shows the relationship between the average values of instanteneous fuel consumption for the three engine speeds.

The datasets were linearly interpolated, obtaining a coefficient of determination $R^{2}$ close to 1 . This reveals very good agreement between the results obtained using the two methods. Thus, the carbon balance method to calculate the fuel consumption per second is shown to be reliable and can be used for results obtained both on the engine dyno bench and under real conditions (RDE methodology).

The specific fuel consumption in the studies conducted was in the range of $238.5 \mathrm{~g} / \mathrm{kWh}$ to $384.4 \mathrm{~g} / \mathrm{kWh}$ (Table IV). The lowest value indicates the highest overall efficiency of the engine, which 


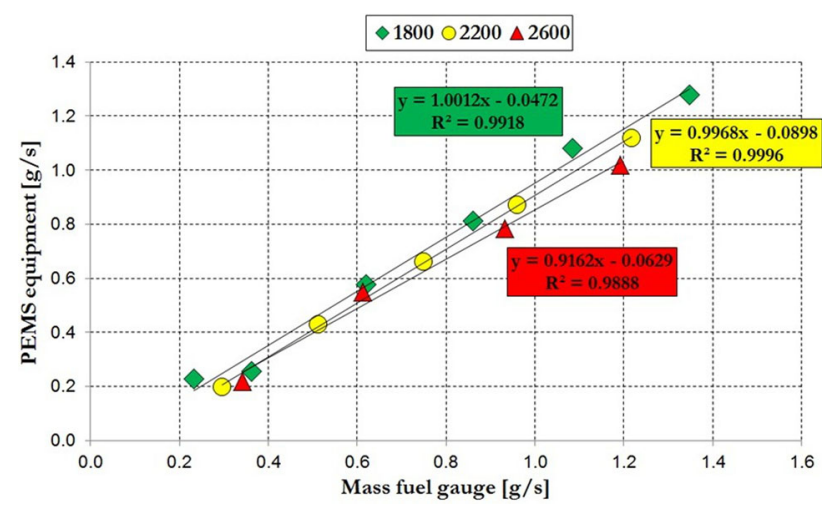

Fig. 7. Linear interpolation of average values of instantenous fuel consumption recorded on an engine test bench and calculated on the basis of parameters measured by the PEMS.

Table IV. Comparison of specific fuel consumption and overall efficiency of tested engine

\begin{tabular}{|c|c|c|c|}
\hline $\begin{array}{l}\text { Engine } \\
\text { speed (rpm) }\end{array}$ & $\begin{array}{c}\text { Torque } \\
\text { (Nm) }\end{array}$ & $\begin{array}{c}\text { BSFC } \\
(\mathbf{g} / \mathbf{k W h})\end{array}$ & $\begin{array}{c}\text { Efficiency } \\
(\%)\end{array}$ \\
\hline 900 & 0 & - & - \\
\hline \multirow{6}{*}{1800} & 0 & - & - \\
\hline & 20 & 295.3 & 28.6 \\
\hline & 40 & 285.6 & 28.7 \\
\hline & 60 & 266.4 & 30.7 \\
\hline & 80 & 258.5 & 31.7 \\
\hline & 100 & 250.8 & 32.6 \\
\hline \multirow[t]{5}{*}{2200} & 0 & - & - \\
\hline & 20 & 368.4 & 22.4 \\
\hline & 40 & 275.5 & 29.8 \\
\hline & 60 & 238.5 & 34.5 \\
\hline & 80 & 228.3 & 35.9 \\
\hline \multirow[t]{5}{*}{2600} & 0 & - & - \\
\hline & 20 & 384.4 & 21.3 \\
\hline & 40 & 283.6 & 20.1 \\
\hline & 60 & 243.8 & 33.7 \\
\hline & 80 & 237.3 & 34.5 \\
\hline
\end{tabular}

was recorded for $S=2200 \mathrm{rpm}$ and loads of $60 \mathrm{Nm}$ and $80 \mathrm{Nm}$, with efficiency of $34.5 \%$ and $35.9 \%$, respectively. For $S=1800 \mathrm{rpm}$ and $T=100 \mathrm{Nm}$, the overall efficiency was $32.6 \%$, whereas for $S=2600 \mathrm{rpm}$ and $T=69 \mathrm{Nm}$, it amounted to $33.7 \%$. For idling (the lowest possible speed of the crankshaft without load) and neutral (increased speed of the crankshaft without load), the BSFC and efficiency were not calculated, because the engine does not generate any power output for transmission to the receiver. It only generates power as needed to overcome the resistance of its operation. Due to the existence of these points in the real road driving conditions, it was decided to also include these points in the analysis. In these cases, only the value of the power generated by ATEG is presented, without determining its effect on overall engine efficiency.

The ATEG power was determined based on the measured voltage and current generated by the thermoelectric modules at each measurement point. The tests began with the engine stabilized thermally and with generator wall temperature not exceeding $50^{\circ} \mathrm{C}$. The duration of the measurement at each point was $60 \mathrm{~s}$ to $90 \mathrm{~s}$. Before recording the parameters after setting the operating point of the engine, the system was given time until temperatures on the walls of the ATEG stabilized. After this period, recording of working parameters was performed. This scheme was adopted in each load characteristic. When changing the range of crankshaft speed, the ATEG conditioning time was significantly prolonged to lower the temperature of its walls to fixed values. This measure was used to reduce the impact of the thermal capacity of the aluminum on the heat flux from the exhaust gases conducted to the thermoelectric modules. Due to the number of measurements and the measured parameters, only exemplary temperature distributions for the exhaust system and on the walls of the heat exchanger (hot side of the thermoelectric modules) are presented herein. Measurements were carried out using water from the sanitary system as coolant with temperature of $10^{\circ} \mathrm{C}$ to $12^{\circ} \mathrm{C}$ at volumetric flow rate of $\sim 0.045 \mathrm{~m}^{3} / \mathrm{h}$.

For neutral gear at $S=1800 \mathrm{rpm}$, the exhaust gas temperature between the turbocharger and the catalytic converter averaged $421.5^{\circ} \mathrm{C}$ throughout the duration of the measurement (Fig. 8). The ATEG was placed at a distance of $\sim 1.5 \mathrm{~m}$ from the end of the catalytic reactor's confusor. The inlet temperature to the generator averaged $91.4^{\circ} \mathrm{C}$. The temperature drop in the generator was $30.3^{\circ} \mathrm{C}$. At maximum load $(100 \mathrm{Nm})$ for the same rotational speed of the engine crankshaft, this drop was $140.8^{\circ} \mathrm{C}$, and the average temperature on the input was $t_{4}=491.5^{\circ} \mathrm{C}$.

For the above measuring point, the highest temperature was recorded on the bottom wall of the heat exchanger (a substantial part of the ATEG), being equal to $t_{51}=45.5^{\circ} \mathrm{C}$ (Fig. 9). The minimum temperature value recorded occurred at the point $t_{11}$. The temperature difference between these two points was $7^{\circ} \mathrm{C}$. This temperature difference is not very significant, meaning that the thermoelectric modules generated similar voltage and current values. Considering the temperature distribution on the walls of the ATEG along each row of modules, it was found that the greatest temperature drop occurred on the left side wall of the generator: $\Delta t_{3}=t_{31}-t_{32}=6.4^{\circ} \mathrm{C}$. On other walls, the recorded temperature differences varied within the range of $0.3^{\circ} \mathrm{C}$ to $4^{\circ} \mathrm{C}$. In the case of maximum load (with $S=1800 \mathrm{rpm}$ ), the highest temperature also occurred at the point $t_{51}$ and was equal to $175^{\circ} \mathrm{C}$.

To determine the effect of the ATEG on the total efficiency of the tested engine based on the data at these measuring points, it was first necessary to determine the power generated by the thermoelectric modules $P_{\text {eATEG }}$ using the values of voltage and 


$$
\mathrm{s}=1800 \mathrm{rpm} \& \mathrm{~T}=0 \mathrm{Nm}
$$

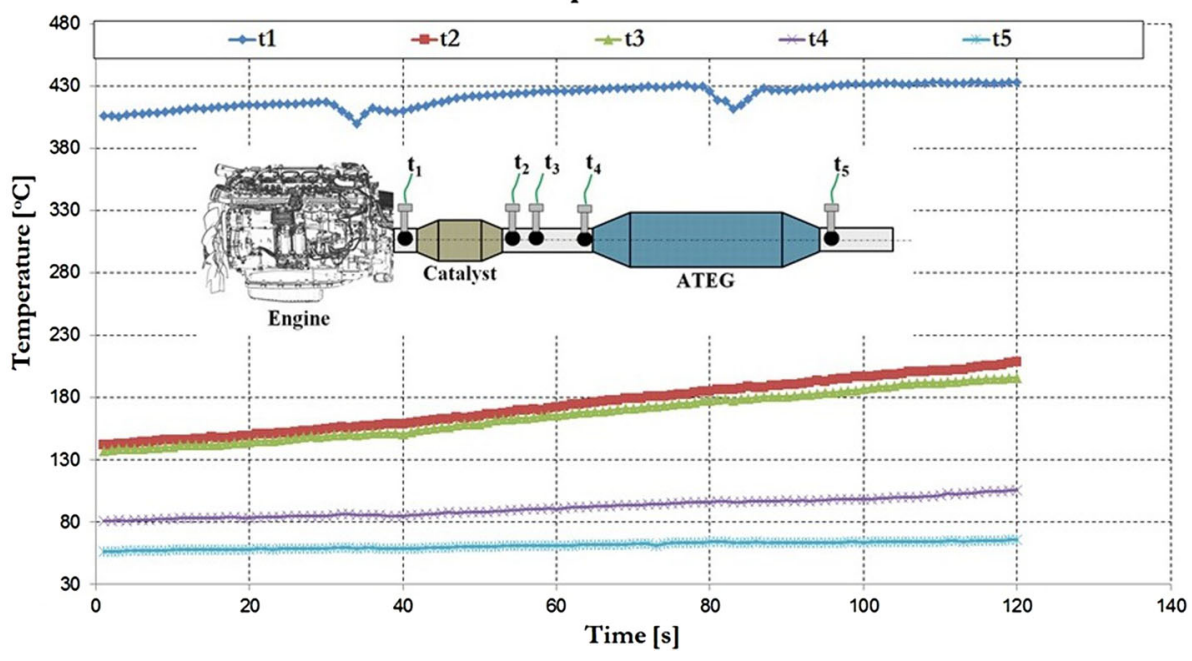

Fig. 8. Temperature distribution in exhaust system of tested engine with ATEG for neutral gear at $S=1800 \mathrm{rpm}$.

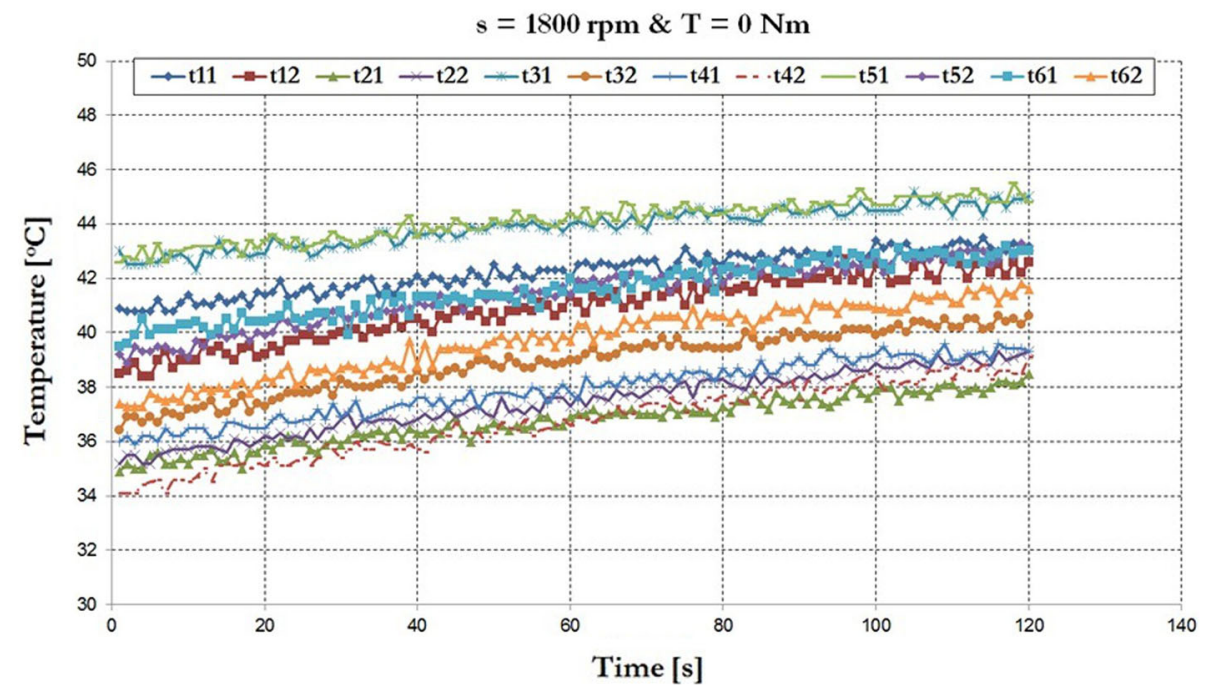

Fig. 9. Temperature distribution on a substantial part of the ATEG heat exchanger-hot side of the thermoelectric modules for neutral gear at $S=1800 \mathrm{rpm}$.

current obtained using the developed measurement system. At all the load characteristics, a trend of increased ATEG power generation with increasing engine torque (Fig. 10) could be observed. This is logical because, at higher loads, the engine produces more exhaust gases at higher temperature. The highest values of $P_{\text {eATEG }}$ were as follows:
(a) $90.1 \mathrm{~W}$ at $1800 \mathrm{rpm}$
(b) $98.8 \mathrm{~W}$ at $2200 \mathrm{rpm}$
(c) $189.3 \mathrm{~W}$ at $2600 \mathrm{rpm}$

For engine idling ( $S=900 \mathrm{rpm}$ and $T=0$ ), $P_{\text {eAteg }}$ did not exceed $1 \mathrm{~W}$. The obtained test results did not reach the ATEG nominal power, which is equal to
$225.6 \mathrm{~W}$. The system generated at most $84 \%$ of its maximum nominal power.

The overall engine efficiency, including the energy generated by the ATEG, was determined using Eq. 2. Then, the obtained values were compared with the determined total engine efficiency (Table IV). According to this assessment, the greatest efficiency improvement was obtained for $S=2600 \mathrm{rpm}$ (Fig. 11). The energy generated by the ATEG over the tested range of engine operation does not constitute a significant share of the total energy. This is mainly a result of the failure to achieve the nominal power of the generator. The analysis above does not take into account the power loss occurring in the ATEG associated with resistance to the flow of exhaust gases. 


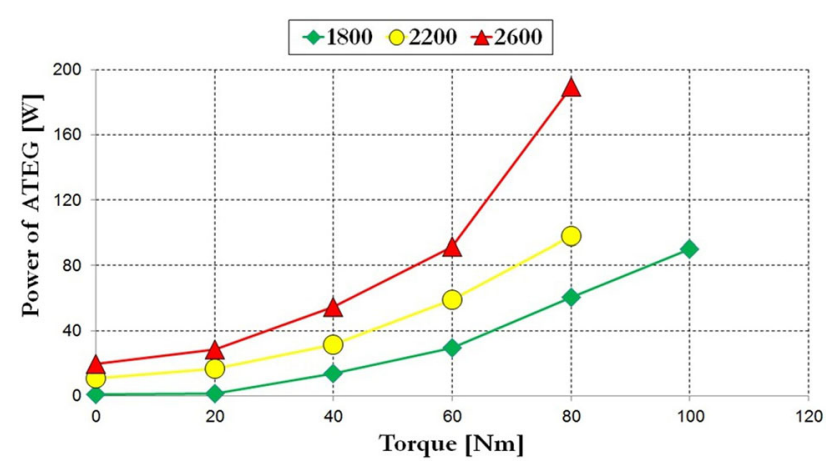

Fig. 10. Calculated power generated by the thermoelectric generator modules (ATEG) during tests.

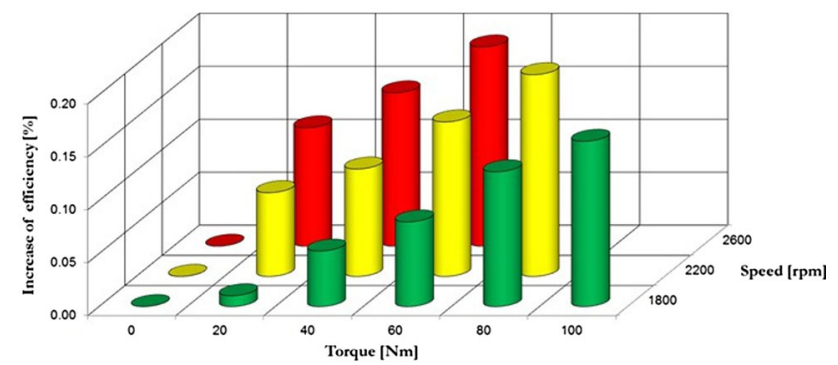

Fig. 11. Increase in overall efficiency of test engine through application of ATEG in exhaust system.

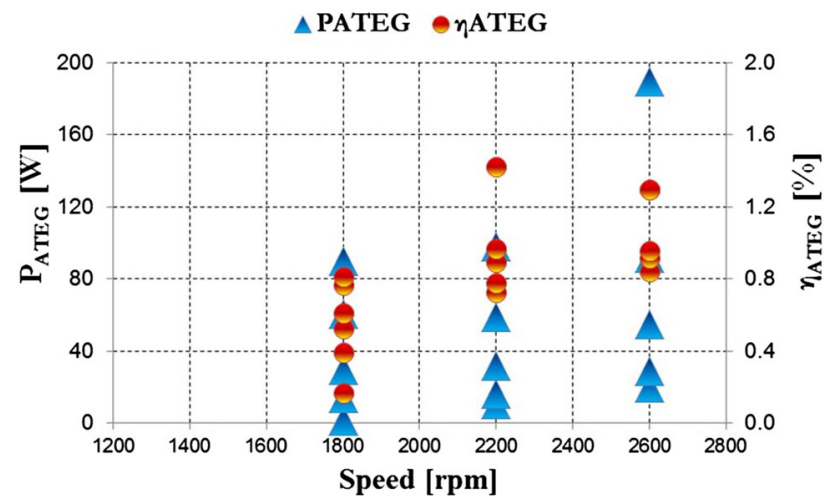

Fig. 12. Power and efficiency of ATEG depending on engine speed.

To determine the efficiency of the ATEG in terms of conversion of exhaust gas thermal energy into electrical energy, one needs to determine the amount of thermal energy from the relation

$$
Q_{\mathrm{EXHAUST}}=\underset{\mathrm{EX}}{\dot{m}} \cdot c_{\mathrm{pEX}} \cdot \Delta T_{\mathrm{EX}}
$$

where $Q_{\text {EXHAust }}$ is the exhaust gas energy losses (enthalpy) (kW), $\underset{\mathrm{EX}}{\dot{m}}$ is the exhaust gas mass flow $(\mathrm{kg} /$ $\mathrm{s}), c_{\mathrm{pEX}}$ is the exhaust gas specific heat at constant pressure $[\mathrm{kJ} /(\mathrm{kg} \mathrm{K})]$, and $\Delta T_{\mathrm{EX}}$ is the exhaust gas temperature (K). The ATEG efficiency $\eta_{\text {TEG }}$ was determined from the relation

$$
\eta_{\mathrm{TEG}}=\frac{P_{\mathrm{ATEG}}}{Q_{\mathrm{EXHAUST}}},
$$

where $\eta_{\mathrm{TEG}}$ is the efficiency of the ATEG (\%), $P_{\mathrm{TEG}}$ is the ATEG power (W), and $Q_{\text {EXHAUST }}$ is the exhaust gas energy losses (enthalpy) (W).

In determining the efficiency $\eta_{\mathrm{ATEG}}$, the power losses resulting from the exhaust gas flow resistance inside the heat exchanger were not taken into account. For the load characteristics at $S=1800$ $\mathrm{rpm}$, the maximum efficiency $\eta_{\mathrm{ATEG}}$ did not exceed $0.8 \%$ (Fig. 12). For the other load characteristics, this efficiency was between $0.5 \%$ and $1.3 \%$.

\section{CONCLUSIONS}

We present a study of the impact of a prototype ATEG on the overall efficiency of a modern SI engine designed in accordance with downsizing principles. The walls of the ATEG exhibited an almost uniform temperature distribution, both along and between the walls. Temperature differences amounted to a maximum of $7^{\circ} \mathrm{C}$ for neutral gear, being larger for higher loads. The measuring points did not reach the maximum power output of the ATEG. Only for $S=2600 \mathrm{rpm}$ and $T=80 \mathrm{Nm}$ was more than $80 \%$ of the nominal power output achieved. Energy losses arising as a result of the flow resistance of exhaust gases in the heat exchanger of the generator were not accounted for in this research. The authors plan to conduct further research including:

(a) Performance measurements of heat energy recovery using the designed prototype ATEG system at operating points reflecting rural and highway driving conditions,

(b) Determination of the energy losses due to the flow resistance of exhaust gases through the heat exchanger,

(c) Adjustment of the design and construction of the ATEG to further increase the efficiency of heat recovery from exhaust gases,

(d) Integration of the ATEG cooling system with that of the vehicle.

\section{ACKNOWLEDGEMENTS}

The research was funded by the National Centre for Research and Development (Narodowe Centrum Badań i Rozwoju) research project within the Applied Research Programme (Contract No. PBS1/A6/7/2012).

\section{OPEN ACCESS}

This article is distributed under the terms of the Creative Commons Attribution 4.0 International License (http://creativecommons.org/licenses/by/4.0/), which permits unrestricted use, distribution, and reproduction in any medium, provided you give 
appropriate credit to the original author(s) and the source, provide a link to the Creative Commons license, and indicate if changes were made.

\section{REFERENCES}

1. F. Aren, L. Mezzan, A. Doyon, H. Suzuki, K. Lee, and T. Becker, The Automotive $\mathrm{CO}_{2}$ Emissions Challenge. 2020 Regulatory Scenario for Passenger Cars (Arthur D. Little, Rome, 2014). http://www.adlittle.com/downloads/tx_adl reports/ADL_AMG_2014_Automotive_CO2_Emissions_ Challenge.pdf.

2. European Commission, Communication from the Commission to the European Parliament, the Council, the European Economic and Social Committee and the Committee of the Regions. An Integrated Industrial Policy for the Globalisation Era Putting Competitiveness and Sustainability at Centre Stage. (European Commission, Brussels, 2010) http://eur-lex.eur opa.eu/LexUriServ/LexUriServ.do?uri=CCO:2010:0614:FIN:E $\mathrm{N}: P D F$.

3. M. Brzeżański and K. Śliwiński, Combust. Engines. 119 (2004).

4. M. Bajerlein and L. Rymaniak, Appl. Mech. Mater. 518, 96101 (2014).
5. P. Bombard, C.M. Invernizzi, and C. Pietra, J. Electron. Mater. (2010). doi:10.1016/j.applthermaleng.2009.08.006.

6. J. Dong, Y.J. Wang, R. Zhang, and B. Wang, J. Electron. Mater. (2014). doi:10.1007/978-3-662-45043-7_15.

7. N. Espinosa, M. Lazard, L. Aixala, and H. Scherrer, J. Electron. Mater. (2010). doi:10.1007/s11664-010-1305-2.

8. J. Merkisz, P. Fuc, P. Lijewski, A. Ziolkowski, and K.T. Wojciechowski, J. Electron. Mater. (2015). doi:10.1007/s 11664-014-3522-6.

9. K. Shiho, P. Soonseo, K. SunKook, and R. Seok-Ho, J. Electron. Mater. (2011). doi:10.1007/s11664-011-1580-6.

10. D. Tatarinov, M. Koppers, G. Bastian, and D. Schramm, J. Electron. Mater. (2013). doi:10.1007/s11664-013-2642-8.

11. SEMTECH ${ }^{\circledR}$ ECOSTAR (Gaseous). Getting Started. Quick Reference Manual. Document: 9510-159 (Sensors Inc., USA, 2014).

12. J. Merkisz, P. Fuc, P. Lijewski, and A. Ziolkowski, Appl. Mech. Mater. 390, 343-349 (2013).

13. Thermoelectric module TMG-241-1.4-1.2 SCTB NORD A Ferrotec Group Company.

14. Fuc, J. Merkisz, P. Lijewski, A. Merkisz-Guranowska, and A. Ziolkowski, in Energy Production and Management in the 21st Century: The Quest for Sustainable Energy (Volume 1), ed. C.A. Brebbia, E.R. Magaril, and M.Y. Khodorovsky (WIT Transactions on Ecology and the Environment, New Forest, 2014), pp. 369-378. 